\title{
Morphological and micromorphological characteristics of Desmodium fruits (Leguminosae: Papilionoideae)
}

\author{
Daiane M. Freitas ${ }^{1}$, Ademir Reis ${ }^{2}$, Roseli L. da Costa Bortoluzzi ${ }^{3} \&$ Marisa Santos ${ }^{4}$ \\ 1. Departamento de Botânica, Centro de Ciências Biológicas, Universidade Federal de Santa Catarina (UFSC), Campus \\ Universitário, Florianópolis CEP 88040-900, Santa Catarina, Brasil and Herbário Barbosa Rodrigues (HBR), Av. \\ Coronel Marcos Konder 800, Itajaí CEP 88301-302, Santa Catarina, Brasil; martinsf.daiane@gmail.com \\ 2. Herbário Barbosa Rodrigues (HBR), Av. Coronel Marcos Konder 800, Itajaí CEP 88301-302, Santa Catarina, Brasil; \\ ademir.reis.ufsc@gmail.com \\ 3. Departamento de Engenharia Florestal, Centro de Ciências Agroveterinárias, Universidade do Estado de Santa \\ Catarina (CAV-UDESC), Lages CEP 88520-000, Santa Catarina, Brasil; rosebortoluzzi@gmail.com \\ 4. Departamento de Botânica, Centro de Ciências Biológicas, Universidade Federal de Santa Catarina (UFSC), Campus \\ Universitário, Florianópolis CEP 88040-900, Santa Catarina, Brasil; marisa.santos@ufsc.br
}

Received 16-I-2014. Corrected 12-VII-2014. Accepted 14-VIII-2014.

\begin{abstract}
The genus Desmodium is represented in Santa Catarina State, Brazil, by 13 species, all with lomentaceous fruits. Shape, size and isthmus margin of loments vary, while the surface is glabrous, or covered by trichomes of different types. Morphological diversity of trichomes becomes particularly relevant to taxonomic description. The trichome types present on the surface of Desmodium fruits provide data for the identification and classification of species in the State. To assess this, three fruits of each species were collected and deposited at two herbaria, HBR and FLOR, in Santa Catarina, Brazil. Some rehydrated samples were examined using light microscopy (LM); and some sections were exposed to the following histochemical reagents: Sudan III for oils and Thionine for mucilage. The structural aspects of trichomes can be classified into uni- or multicellular and may still be simple, i.e., nonglandular or glandular. Using scanning electron microscopy (SEM), five types of trichomes were identified and analyzed among the Desmodium species studied: uncinate, uniseriate, globose multicellular, globose unicellular and subulate. Characteristics, such as loment margin and article form, glabrescent or pillous indument, trichome type, with or without papillous epidermal cells and epicuticular striations, showed relevant diagnostic value. An identification key was developed for Desmodium species from Santa Catarina State, Brazil, based on macro and micromorphological characters of the fruit. Rev. Biol. Trop. 62 (4): 1597-1608. Epub 2014 December 01.
\end{abstract}

Key words: dispersion, identification key, scanning electron microscopy (SEM), secretory structures, taxonomy, trichomes.

The Desmodium Desv. genus (Leguminosae, subfamily Papilionoideae; Ohashi, 2014) is included in the tribe Desmodieae and comprises about 524-530 species, with greater diversity in Southeast Asia, Mexico and South America (Ohashi, 2014). According to Lima, Oliveira and Tozzi (2014), 33 species are distributed throughout Brazil and 16 species in Santa Catarina State. The genus is characterized by shrubby or subshrubby habit, uni- or trifoliate leaves, lomentaceous or craspedium-type fruit (whose pericarp splits into monospermous articles), and uncinate (hooked) trichomes, usually present on vegetative parts and fruits (Oliveira, 1983; Setubal, Lima, \& Grings, 2010; Lima, 2011). In these species, the fruits can be sessile or stipitate with central isthmus, either eccentric or marginal, and the upper margin of the fruit, either straight or sinuous, but the lower margin is always sinuous.

According to Azevedo (1981), Desmodium species can have glabrescent or densely 
pubescent fruit, and the trichomes can be uncinate or straight, uniseriate or multicellular, and long or short. Oliveira $(1983,1990)$ also cited different trichome types on the fruit surface for this genus: uncinate, straight glandular and straight nonglandular. Werker (2000) pointed out that trichomes are uni- or multicellular appendices originating from single epidermal cells present in various plant organs, such as vegetative parts, leaves, bracts, and roots near the apical meristem, or reproductive organs, including sepals, petals, stamens, gynoecium, fruit and seeds.

Epidermal surface ornamentation, such as conformations of the outer cell wall, trichomes and epicuticular waxes, contribute to maintaining inner water balance (Fahn, \& Cutler, 1992). Convexity of epidermal cells in periclinal walls confers a greater ability to reflect solar radiation, with the walls acting as filters for the inner tissues, allowing adaptation to more xeric environments (Larcher, 2000). The amount of epicuticular waxes has been correlated to sunlight intensity (Barthlott, 1990); therefore, this type of deposition has been regarded as a taxonomic character (Barthlott et al., 1998). Since trichome density can change with environmental conditions, trichome type may be employed to identify a particular taxon.

Several studies have demonstrated the use of scanning electron microscopy (SEM) in angiosperm taxonomy, and many analyses have been performed on the surface of fruits and seeds in different plant groups. For example, Ávalos and Salinas (2003) found that trichomes of Quercus L. (Fagaceae) leaf surfaces could be used for delimiting species in that trichomes showed variation in shape, intensity, size and quantity of cells, as well as function, being either glandular or nonglandular. Agbagwa and Okoli (2005) used fruit epidermis micromorphology to study the systematics of Abrus Adans. (Papilionoideae). Ritter and Miotto (2006) used SEM to study fruit and seed surfaces for the taxonomy of 15 taxa of Mikania Willd. (Asteraceae). Akcin (2008) identified different microstructural patterns on the surface of seeds and fruits from
Cynoglossum L. (Boraginaceae) species. Kaya, Ünal, Özgökçe, Doğan, and Martin (2011) also used SEM to study fruit and seed surface characteristics to study the taxonomy of 11 genera of Brassicaceae.

The present research aimed to contribute to the identification and classification of the Desmodium genus from Santa Catarina State, Brazil, based on fruit macro- and micromorphology, emphasizing on trichome type.

\section{MATERIALS AND METHODS}

For this study, specimens with fruits were collected during fieldwork conducted between November 2010 and April 2011, in Santa Catarina State, Brazil. These specimens were deposited at the Herbarium "Barbosa Rodrigues" (HBR) and the Botany Department Herbarium, Federal University of Santa Catarina (FLOR), with abbreviations according to Holmgren, Holmgren, and Barnett (1990). The species that were not found in the field were studied starting from ancient specimens deposited in HBR.

Three fruits of each species were collected from the specimens. The specimens were: Desmodium adscendens (Sw.) DC (D. M. Freitas 82 [21/03/2010] FLOR/HBR, 165 [07/02/2011] FLOR/HBR, 179 [17/03/2011] HBR); D. affine Schltdl. (R. Reitz \& R. M. Klein 16752 [01/01/1964] HBR; D. M. Freitas 97 [21/03/2010] HBR, 192 [18/03/2011] FLOR/HBR); D. barbatum (L.) Benth. (D. M. Freitas 168 [16/03/2011] HBR, 186 [17/03/2011] FLOR/HBR, 203 [23/04/2011] FLOR/HBR); D. cuneatum Hook. \& Arn. (Rambo 59229 [03/02/1956] HBR; R. Reitz 5296 [26/01/1953] HBR, 6596 [04/02/19630] HBR); D. subsecundum Vogel (R. Reitz \& R. M. Klein 3978 [13/04/1956] HBR; A. Reis \& D. M. Freitas 2602 [13/02/2011] FLOR/ HBR, 2616 [23/02/2011] FLOR/HBR); $D$. incanum DC. (D. M. Freitas 166 [07/02/2011] FLOR/HBR, 187 [18/03/2011] HBR, 204 [10/06/2011] FLOR/HBR); D. leiocarpum (Spreng.) G.Don. (A. Reis 2617 [08/03/2011] FLOR/HBR, 2620 [09/02/2011] FLOR/HBR; R. Reitz \& R. M. Klein 12294 [22/02/1962] 
HBR); D. pachyrhizum Vogel (L. B. Smith \& R. Reitz 9934 [06/01/1957] HBR; L. B. Smith et al. 14458 [14/01/1965] HBR; R. Reitz 5220 [26/01/1953] HBR); D. polygaloides Chodat \& Hassl. (R. Reitz 4328 [24/01/1952] HBR; R. Reitz \& R. M. Klein 11810 [09/01/1962] HBR, 16579 [29/12/1963] HBR); D. subsericeum Malme (R. Reitz \& R. M. Klein 8774 [24/04/1959] HBR, 12243 [22/02/1962] HBR; D. M. Freitas \& A. Reis 107A [27/05/2010] FLOR/HBR); D. tortuosum (Sw.) DC. (D. M. Freitas \& A. Reis 145 [12/11/2010] FLOR/HBR; D. M. Freitas \& A. Zanin 185 [17/03/2011] FLOR/HBR; A. Reis 2628 [13/03/2011] FLOR/HBR); D. triarticulatum Malme (D. M. Freitas 93 [21/03/2010] FLOR/HBR, 200 [22/04/2011] FLOR/HBR; A. Reis 2621 [09/03/2011] FLOR/HBR) and D. uncinatum (Jacq.) DC. (D. M. Freitas 195 [22/4/2011] FLOR/HBR; A. Reis 2623 [09/3/2011] FLOR/HBR; R. Reitz \& R. M. Klein 14828 [13/4/1963] HBR).

Lima et al. (2014) reported the occurrence of 16 species of Desmodium in Santa Catarina State. However, four species noted by these researchers, including $D$. album, $D$. arechavaletae, D. triflorum and D. venosum, were not found in either HBR or FLOR, nor were they found in the many field collections covering almost every Brazilian state. Meanwhile, in this investigation, the occurrence of D. leiocarpum was registered, but not previously reported to Santa Catarina State by Lima et al. (2014).

Images of fruits were captured with a stereoscopic microscope (Olympus SZ-40, Tokyo, Japan) with a digital camera (Sony Cybershot $^{\mathrm{TM}}$ compact digital camera, 7.2 megapixels, Tokyo, Japan).

Three fruits of each species (total of 39 samples) were rehydrated in distilled water with some drops of detergent and heated to $90^{\circ} \mathrm{C}$ (Bersier \& Bocquet, 1960). SEM analysis was carried out in the Central Laboratory for Electron Microscopy at the Federal University of Santa Catarina - LCME-UFSC. After rehydration, the samples were fixed in glutaraldehyde $2.5 \%, 0.1 \mathrm{M}$ sodium phosphate buffer, $\mathrm{pH} 7.2$, and then dehydrated in ethanol. Samples were critical point dried with liquid $\mathrm{CO}_{2}$ (Leica EM model CDP 300, Wetzlar, Germany). Dried samples were placed on aluminum supports with the aid of double-sided carbon tape and coated with $20 \mathrm{~nm}$ gold in a metallizer (Leica EM model SCD 500, Wetzlar, Germany). The analysis was then carried out at the LCME using SEM (JEOL JSM-6390 LV, Tokyo, Japan).

Thirteen rehydrated samples were examined using light microscopy (LM). Furthermore, two fruits of each species were freehand sectioned transversely and longitudinally, with a razor blade. Sections were exposed to the following histochemical reagents: Sudan III for oils and Thionine for mucilage (Costa, 1982), with the purpose of test presence of chemicals (oil or mucilage) on the trichomes.

\section{RESULTS}

Desmodium species have lomentaceous fruits (Fig. 1). While uncinate trichomes were observed, other types can occur, including uniseriate, globose and subulate. Loments of some Desmodium species were sinuous at both edges, or the upper edge was straight, while the lower was wavy (Fig. 1). Two species, $D$. subsecundum and D. leiocarpum, had glabrescent loments, while the loments of species were pubescent with differential features (Fig. 2). The shape of the articles, presence of distinct types of trichomes and aspects of epidermal cells, with epicuticular ridges and papillae, also proved to be useful in distinguishing among species (Fig. 1, Fig. 2, Fig. 3, Fig. 4, Fig. 5 y Fig. 6).

The structural aspects of trichomes can be classified into uni- or multicellular and may still be simple, i.e., nonglandular or glandular. Five morphological types of trichomes were recognized and could be classified as follows:

1. Uncinate trichome (Fig. 3): glandular, with oil secretion at the base in all species. This trichome type showed dense distribution in $D$. adescendens, D. affine, D. incanum, 


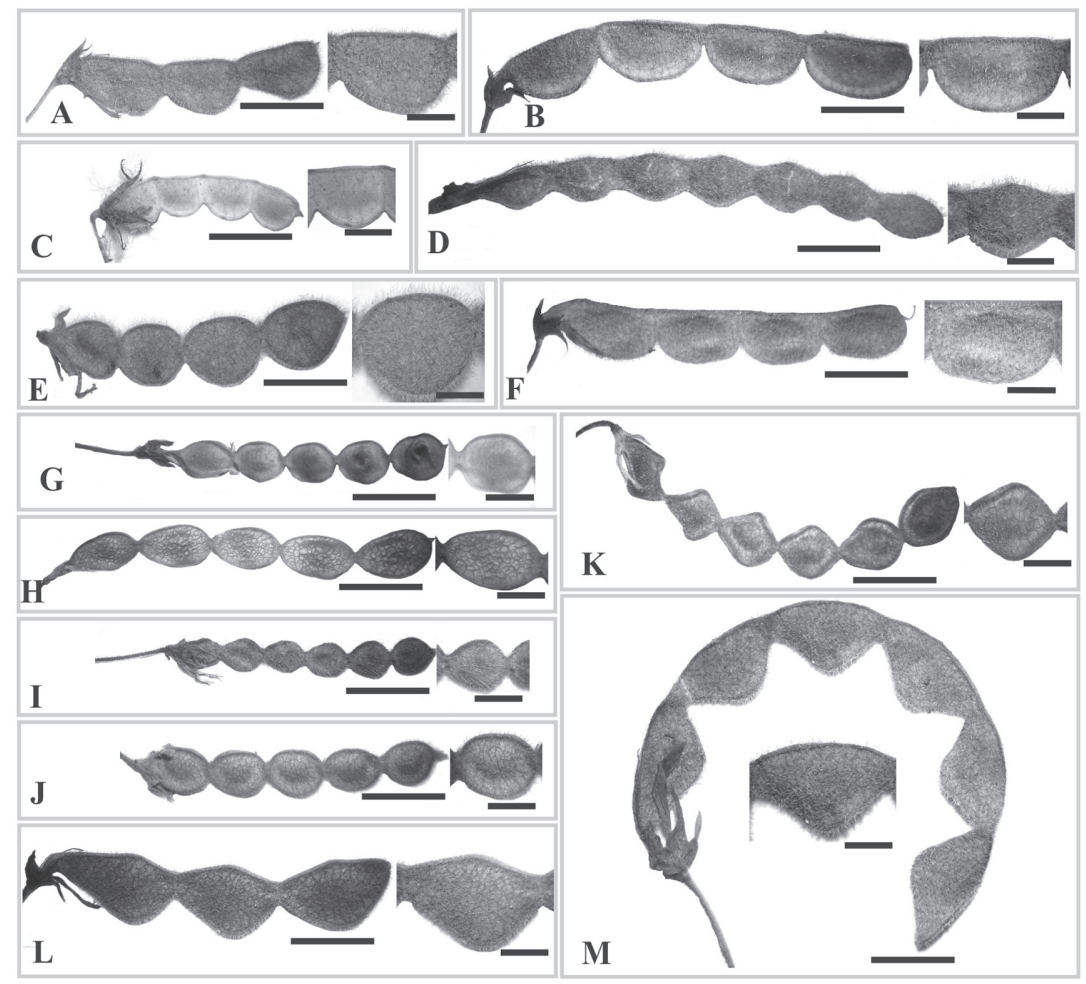

Fig. 1. Photomicrographs of loments and articles (bar in loment $=5 \mathrm{~mm} / \mathrm{bar}$ in article $=2 \mathrm{~mm}$ ). A- Desmodium adscendens (Sw.) DC. (Freitas, D. M. 165). B- D. affine Schltdl. (Freitas, D. M. 192). C- D. barbatum (L.) Benth. (Freitas, D. M. 203). D- D. subsericeum Malme (Freitas, D. M. \& Reis, A. 107a). E- D. cuneatum Hook \& Arn. (Reitz, R. 5296). F- D. incanum DC. (Freitas, D. M. 187). G- D. subsecundum Vogel (Reitz, R. \& Klein, R. M. 3978). H- D. leiocarpum (Spreng.) G. Don. (Reitz, R. \& Klein, R. M. 12294). I- D. pachyrhizum Vogel (Reitz, R. 5220). J- D. polygaloides Chodat \& Hassl. (Reitz, R. \& Klein, R. M. 11810). K- D. tortuosum (Sw.) DC. (Reis, A. 2628). L- D. triarticulatum Malme (Freitas, D. M. 200 ). M- D. uncinatum (Jacq.) DC. (Freitas, D. M. 195).

D. uncinatum, D. subsericeum and $D$. triarticulatum (Fig. 2A, Fig. 2B, Fig. 2E, Fig. 2I, Fig. 2K and Fig. 2L); however, they were sparse in other species (Fig. 2C, Fig. 2D, Fig. 2F, Fig. 2G, Fig. 2H, Fig. 2J and Fig. 2M).

2. Globular multicellular trichome (Fig. 4A, Fig 4B, Fig. 4C, Fig. 4D, Fig.4E, Fig. 4F, Fig. 4G, Fig.4H, Fig.4I, Fig. 4J, Fig. 4K): glandular, secretion of oil or mucilage throughout the structure. These trichomes were not found in D. pachyrhizum or $D$. polygaloides; however, they were present in all other species and showed a positive reaction to Thionine, indicating the presence of mucilage, except $D$. subsecundum which reacted only with Sudan III for oils.

3. Globular unicellular trichome (Fig. 4L): glandular, secretion unspecified (non-oily and non-mucilaginous). This trichome type was only present in D. uncinatum, and it showed no positive reaction to oil or mucilage. The substance could not be identified in this work.

4. Uniseriate trichome (Fig. 5): glandular, secretion throughout the structure. This trichome type was absent in $D$. subsecundum. When these trichomes were present, secreted oil was present in D. pachyrhizum, 


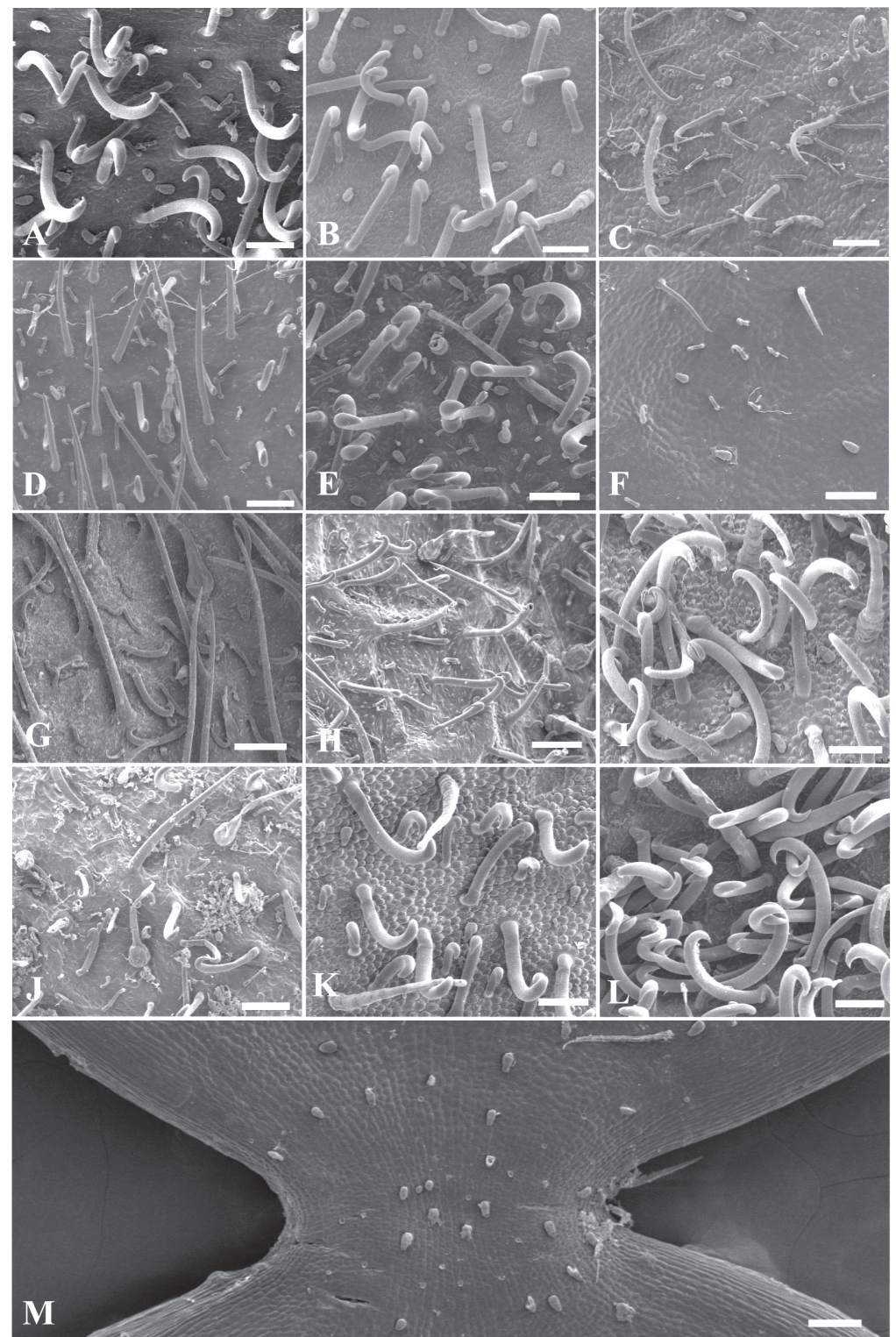

Fig. 2. Scanning electromicrographs of the fruit surface (bar=100 $\mu \mathrm{m})$. A- Desmodium adscendens (Sw.) DC. (Freitas, D. M. 165). B- D. affine Schltdl. (Freitas, D. M. 192). C- D. barbatum (L.) Benth. (Freitas, D. M. 203). D- D. cuneatum Hook \& Arn. (Rambo, B. 59229). E- D. incanum DC. (Freitas, D. M. 166). F- D. leiocarpum (Spreng.) G. Don. (Reis, A. 2616). G- D. pachyrhizum Vogel (Smith, L. B. \& Reitz, R. 9934). H- D. polygaloides Chodat \& Hassl. (Reitz, R. \& Klein, R. M. 11810). I- D. subsericeum Malme (Freitas, D. M. \& Reis, A. 107a). J- D. tortuosum (Sw.) DC. (Reis, A. 2628). K- D. triarticulatum Malme (Freitas, D. M. 93). L- D. uncinatum (Jacq.) DC. (Reitz, R. \& Klein, R. M. 14828). M- D. subsecundum Vogel (Reis, A. \& Freitas, D. M. 2616). 


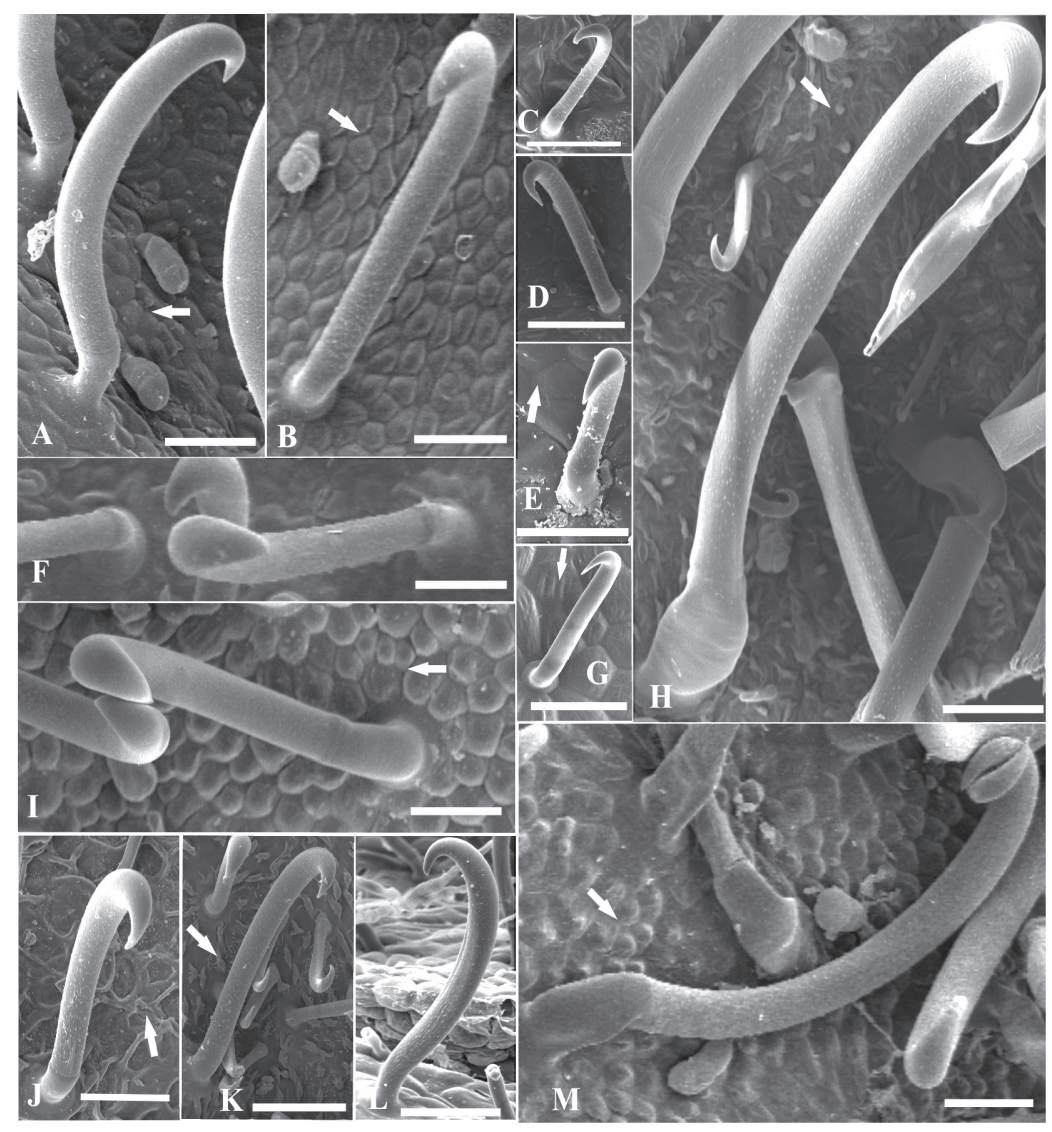

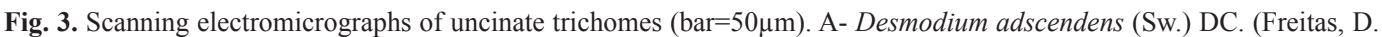
M. 165), arrow: papillary cells. B- D. affine Schltdl. (Freitas, D. M. 192), arrow: papillary cells. C- D. barbatum (L.) Benth. (Freitas, D. M. 168). D- D. cuneatum Hook. \& Arn. (Rambo, B. 59229). E- D. subsecundum Vogel (Reis, A \& Freitas, D. M. 2602), arrow: papillary cells. F- D. incanum DC. (Freitas, D. M. 166). G- D. leiocarpum (Spreng.) G. Don. (Reis, A. 2620), arrow: epicuticular striations. H- D. uncinatum (Jacq.) DC. (Reitz, R. \& Klein, R. M. 10802), arrow: epicuticular wax. I- D. triarticulatum Malme. (Freitas, D. M. 93), arrow: papillary cells. J- D. pachyrhizum Vogel (Smith, L. B. et al. 14458), arrow: epicuticular wax. K- D. polygaloides Chodat \& Hassl. (Reitz, R. \& Klein, R. M. 16579), arrow: epicuticular wax. L- D. tortuosum (Sw.) DC. (Freitas, D. M. \& Reis, A. 145). M- D. subsericeum Malme. (Freitas, D. M. \& Reis, A. 107a), arrow: papillary cells.

D. cuneatum and D. polygaloides, but mucilage was present in D. adescendens, D. affine, D. barbatum, D. leiocarpum, $D$. incanum, D. triarticulatum, D. tortuosum, D. subsecundum and D. uncinatum.

5. Subulate trichome (Fig. 6): glandular, secretion (oil) at the base, when present. This trichome type occurs in $D$. barbatum, D. pachyrhizum, D. cuneatum, D. subsecundum, D. leiocarpum and D. polygaloides.
Epicuticular wax depositions were found on D. pachyrhizum (Fig. 3J, Fig. 5I), D. polygaloides (Fig. 3K, Fig. 5G, Fig. 6D). D. uncinatum (Fig. $3 \mathrm{H}$ ) and D. cuneatum (Fig. $5 \mathrm{H}$ ), while D. leiocarpum (Fig. 3G, Fig. 5D) showed the presence of epicuticular streaks on the epidermal surface. The epidermal cells in 9 of the 13 species were papillose, characterized by the convexity of the outer periclinal wall, which was more pronounced in D. affine (Fig. 3B) and D. triarticulatum (Fig. 3I, Fig. 5F), but 


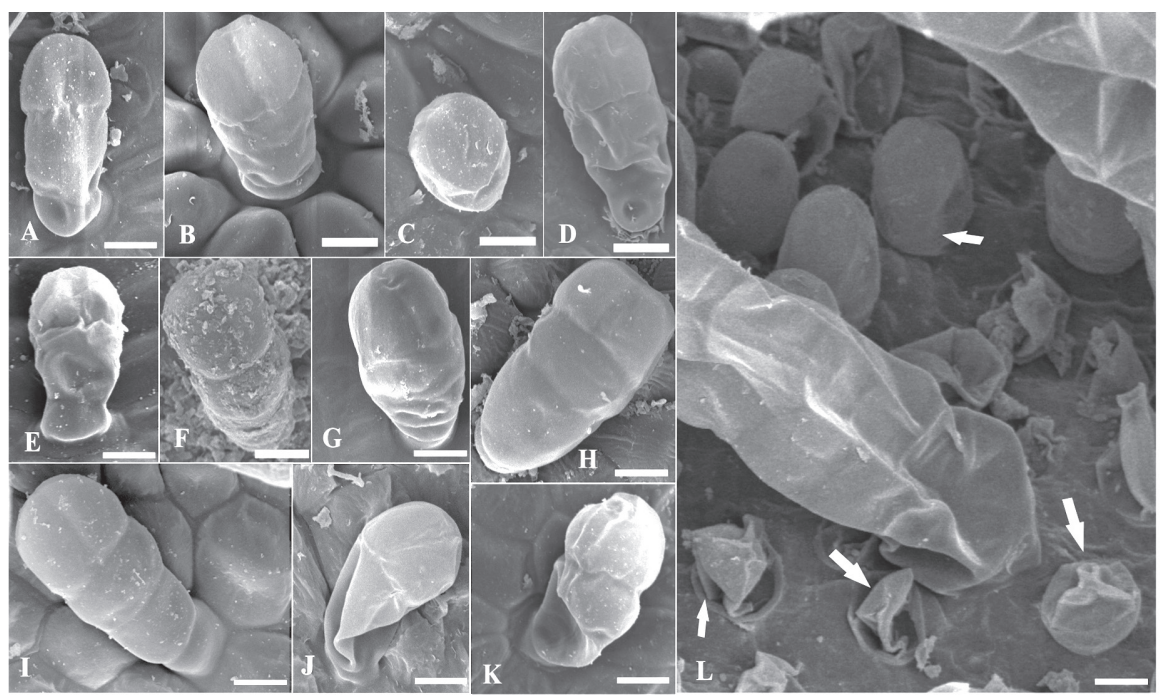

Fig. 4. Scanning electromicrographs of (A-K) globose multicellular trichomes and (L) globose unicellular trichomes

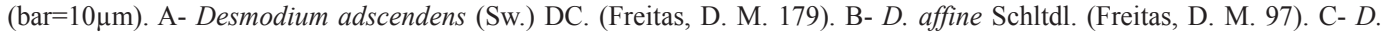
barbatum (L.) Benth. (Freitas, D. M. 203). D- D. cuneatum Hook. \& Arn. (Rambo, B. 59229). E- D. subsecundum Vogel (Reis, A. \& Freitas, D. M. 2616). F- D. incanum DC. (Freitas, D. M. 204). G- D. leiocarpum (Spreng.) G. Don. (Reis, A. 2617). H- D. subsericeum Malme (Freitas, D. M. \& Reis, A. 107a). I- D. triarticulatum Malme (Reis, A. 2621). J-L- D. uncinatum (Jacq.) DC. (Reitz, R. \& Klein, R. M. 14828), J- globose multicellular trichomes, L- arrow: globose unicellular trichome. K- D. tortuosum (Sw.) DC. (Reis, A. 2628).

also present in D. adscendens (Fig. 3A), D. barbatum (Fig. 5C), D. subsecundum (Fig. 3E), D. leiocarpum (Fig. 5D, Fig. 6E), D. subsericeum
(Fig. 3M, Fig. 5K) and D. tortuosum (Fig. 5J, Fig. 6C). In fruits of Desmodium, stomata were found on the fruit surface (Fig. 5B).

\section{Key for identification of Desmodium species in Santa Catarina, Brazil, using fruit macro- and micromorphology}

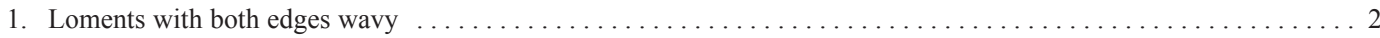

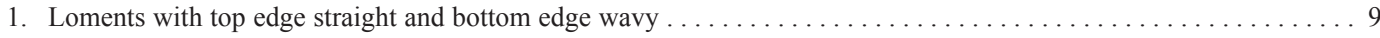

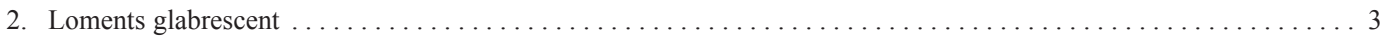

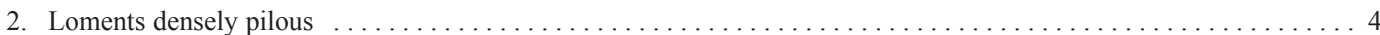

3. Loments with orbicular articles, without uniseriate trichomes $\ldots \ldots \ldots \ldots \ldots \ldots \ldots \ldots \ldots \ldots$. subsecundum

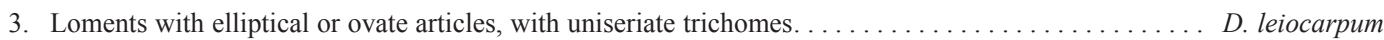

4. Loments with twisted articles $\ldots \ldots \ldots \ldots \ldots \ldots \ldots \ldots \ldots \ldots \ldots \ldots \ldots \ldots \ldots \ldots \ldots \ldots \ldots \ldots \ldots$ tortuosum

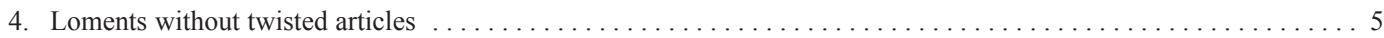

5. Loments with articles triangular or subtriangular, without trichomes subulate $\ldots \ldots \ldots \ldots \ldots \ldots \ldots \ldots$

5. Loments with articles elliptical, orbicular or suborbicular; trichomes subulate type $\ldots \ldots \ldots \ldots \ldots \ldots \ldots \ldots$

6. Articles subtriangulate, ca. 3-5 x 2-3mm, epidermal cells slightly papillose . . . . . . . . . . D. subsericeum

6. Articles triangulate, ca. 6-7 x 4mm; epidermal cells strongly papillose $\ldots \ldots \ldots \ldots \ldots \ldots \ldots$. triarticulatum

7. Loments with isthmuses subcentral, articles suborbicular, $4-6 \times 3-5 \mathrm{~mm}$, globular multicellular

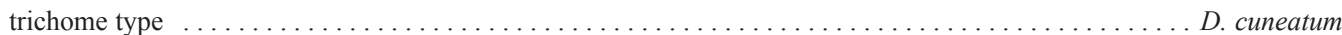

7. Loments with isthmuses central, articles elliptical or orbicular, 3-5 x 1-3mm, without globular

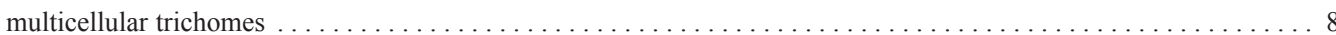




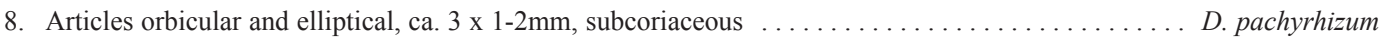

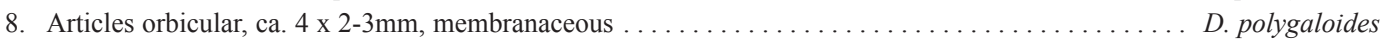

9. Articles with sparse uncinate trichomes, with subulate trichomes $\ldots \ldots \ldots \ldots \ldots \ldots \ldots \ldots \ldots \ldots$. barbatum

9. Articles with abundant uncinate trichomes, without subulate trichomes $\ldots \ldots \ldots \ldots \ldots \ldots \ldots \ldots \ldots \ldots \ldots$

10. Articles triangular, with globose unicellular trichomes and epicuticular wax depositions .......... D. uncinatum

10. Articles square, ovate-depressed or round-depressed, without globose unicellular trichomes and

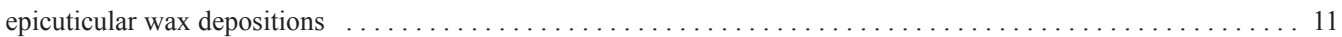

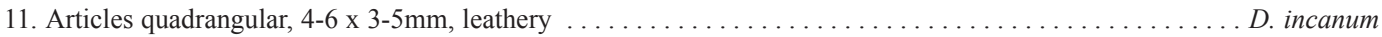

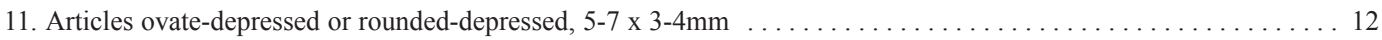

12. Articles ovate-depressed with epidermal cells strongly papillose $\ldots \ldots \ldots \ldots \ldots \ldots \ldots \ldots \ldots \ldots \ldots$ affine

12. Articles rounded-depressed; epidermal cells slightly papillose $\ldots \ldots \ldots \ldots \ldots \ldots \ldots \ldots \ldots \ldots \ldots$. adscendens

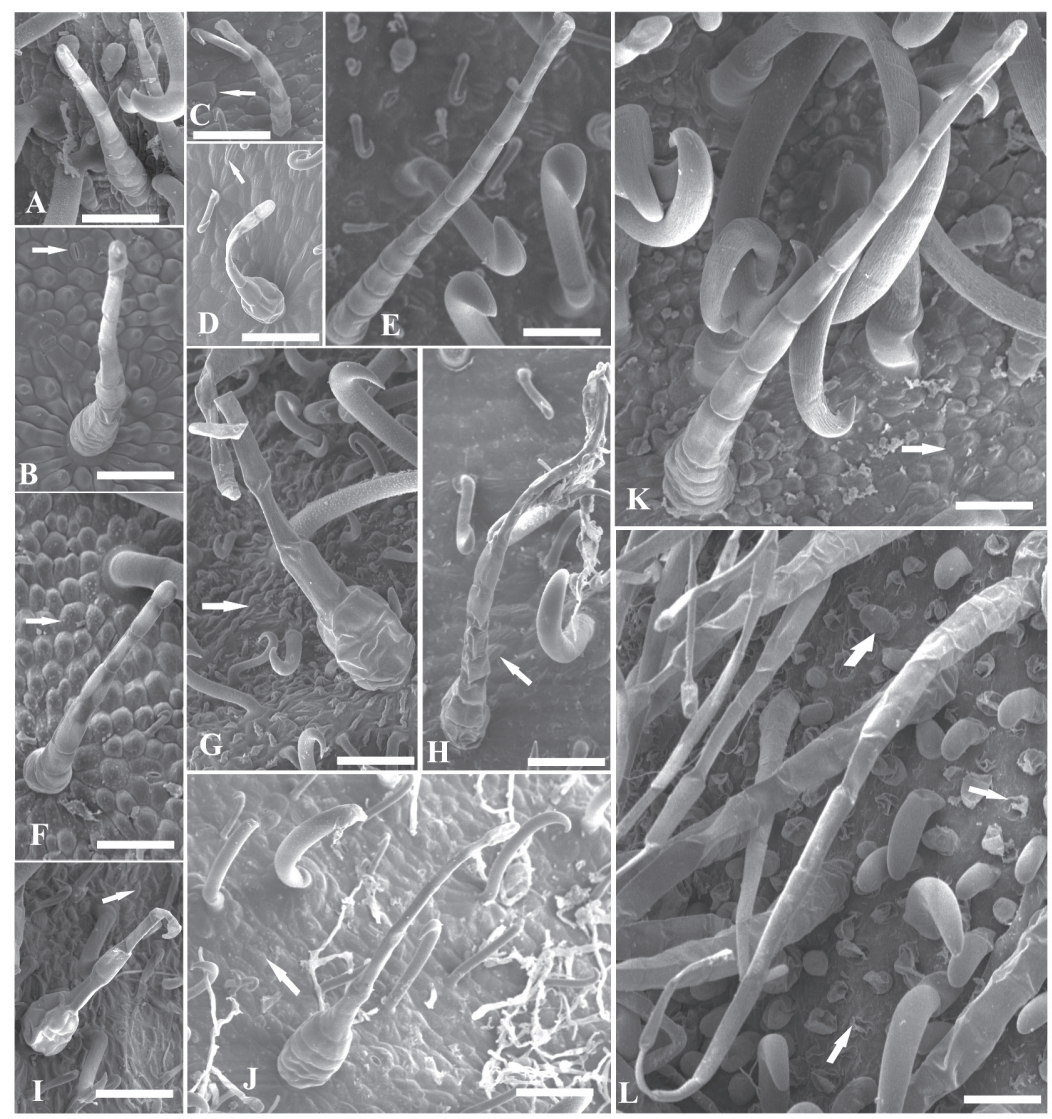

Fig. 5. Scanning electromicrographs of uniseriate trichomes (bar $=50 \mu \mathrm{m})$. A- Desmodium adscendens (Sw.) DC. (Freitas, D. M. 165). B- D. affine Schltdl. (Freitas, D. M. 97), arrow: stoma. C- D. barbatum (L.) Benth. (Freitas, D. M. 203), arrow: papillary cells. D- D. leiocarpum (Spreng.) G. Don. (Reis, A. 2620), arrow: epicuticular striations and papillary cells. E- $D$. incanum DC. (Freitas, D. M. 166). F- D. triarticulatum Malme (Freitas, D. M. 93), arrow: papillary cells. G- D. polygaloides Chodat \& Hassl. (Reitz, R. \& Klein, R. M. 16579), arrow: epicuticular wax. H- D. cuneatum Hook. \& Arn. (Rambo, B. 59229), arrow: epicuticular striations. I- D. pachyrhizum Vogel (Smith, L. B. et al. 14458), arrow: epicuticular wax. J- D. tortuosum (Sw.) DC. (Freitas, D. M. \& Reis, A. 145), arrow: papillary cells. K- D. subsericeum Malme (Freitas, D. M. \& Reis, A. 107a), arrow: papillary cells. L- D. uncinatum (Jacq.) DC. (Reitz, R. \& Klein, R. M. 14828), arrow: globose unicellular trichome. 


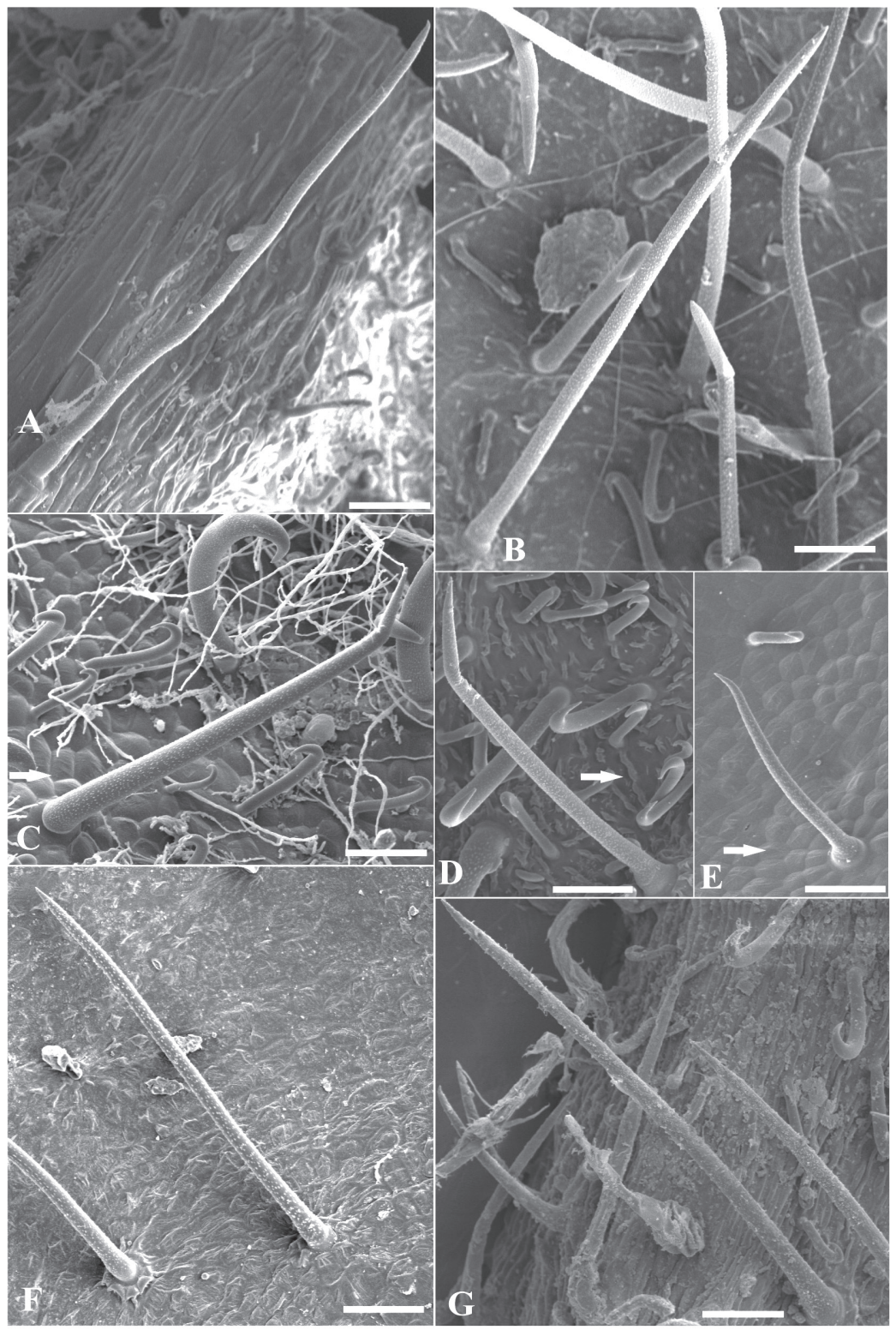

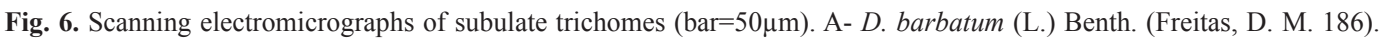
B- D. cuneatum Hook. \& Arn. (Reitz, R. 5296). C- D. tortuosum (Sw.) DC. (Freitas, D. M. \& Reis, A. 185), arrow: papillary cells. D- D. polygaloides Chodat \& Hassl. (Reitz, R. \& Klein, R. M. 16579), arrow: epicuticular wax. E- D. leiocarpum (Spreng.) G. Don. (Reis, A. 2617), arrow: papillary cells. F- D. subsecundum Vogel (Reitz, R. \& Klein, R. M. 3978 ). G- D. pachyrhizum Vogel (Smith, L. B. et al. 14458). 


\section{DISCUSSION}

The presence of trichomes on plants, as noted by Werker (2000), may serve as a mechanical barrier against various external factors, such as herbivores, pathogens, intense light, and temperature extremes. In the case of glandular trichomes, these structures can provide chemical protection to the plant by secreting substances, such as mucilage, resins or lipids, which may poison or deter herbivores and pathogens. Trichomes may also aid in dispersion, using, for example, bristles or hooks attached to the fur and feathers of animals.

Uncinate trichomes were present in all species analyzed. Such hook-shaped trichomes play an important role in the dispersion of the diaspore by promoting fixation to the skin of animals and the clothing of humans. However, by comparing these species, it was observed that the length of trichomes is distinctly variable in different species, and that the distribution of these structures on the surface of the fruit can be dense or sparse, also depending on the species. While significant differences can be observed among some trichomes, homogeneity is seen among others. From these results, it can be concluded that dispersal of fruit in $D$. adscendens, D. affine, D. incanum, $D$. subsericeum, $D$. triarticulatum and $D$. uncinatum is epizoocoric since uncinate trichomes were more densely distributed on the fruit surface. However, in D. barbatum, D. cuneatum, D. pachyrhizum, D. polygaloides and D. tortuosum, the uncinate trichomes are sparse, indicating two forms of fruit dispersal: epizoocoric and anemocoric. For D. subsecundum and $D$. leiocarpum, uncinate trichomes are short and sparsely distributed on the fruit surface, suggesting the anemocoric type. As already mentioned by Barroso, Morim, Peixoto, and Ichaso (1999), most species of Desmodium present articles covered with uncinate trichomes, which make them suitable for epizoocoric dispersion; however, anemocoric dispersion is also observed in the genus. Moreover, according to Lima (2011), the presence of uncinate trichomes is uncommon in fruits of all species, and possibly, the loss of such trichomes is associated with changes in dispersal strategies.

Globular multicellular trichomes were small in size and their presence could only be detected by optical or scanning electronic microscopy. These trichomes were present in 11 of the 13 species examined. Globose unicellular trichomes were only found on D. uncinatum.

Other surface features were observed in the epidermal ultrastructural examination of the fruit surfaces. Specifically, for example, epidermal cells were papillose in nine of the 13 species. While this feature can be used to help identify a given species, it should be done with caution because it may be in which such species occurs. The convexity of the outer walls of the epidermal cells, according Larcher (2000), plays an important role in xeric environments, reflecting solar radiation, while minimizing the effects of high solar irradiation on internal tissues.

Epicuticular wax depositions were found on three species, including $D$. pachyrhizum, $D$. polygaloides and $D$. uncinatum. These depositions also reflect environmental conditions, with the greatest wax deposits occurring with higher exposure to solar radiation (Cutter, 1978; Barthlott, 1990). However, the type of deposition may vary and has been considered a taxonomic character (Barthlott et al., 1998). Furthermore, D. cuneatum and D. leiocarpum showed epicuticular streaks on the epidermal surface, which is also related to xeric environments and may, therefore, be complementary to the characterization of the species, but not a determinant of identification. According to Monteiro, Castro, and Giulietti (1985), the presence of epicuticular ornamentation can provide protection for the stomata or increase the reflection of sunlight. In fruits of Desmodium, the presence of stomata may promote evaporation to maintain homeostasis of internal water supply in environments exposed to excessive solar irradiation.

The data on macro- and micromorphological characteristics of the fruit enabled the development of an identification key of 
Desmodium species in Santa Catarina, Brazil. The following features were shown to be useful for the design of this key: form of the loment margin, from of article, indument glabrescent or pillous, trichome type, papillous epidermal cells present or not, and epicuticular striations present or not.

\section{ACKNOWLEDGMENTS}

We thank the administrators the Herbarium "Barbosa Rodrigues" (HBR) by loan of specimens used in this study and support from Deise Rebelo Consoni for SEM analysis in Central Laboratory for Electron Microscopy at the Federal University of Santa Catarina -LCMEUFSC, Brazil.

\section{RESUMEN}

Características morfológicas y micromorfológicos de frutos Desmodium (Leguminosae: Papilionoideae). El género Desmodium está representado en Santa Catarina, Brasil, por 13 especies, todas con frutos lomentaceos. Los lomentos han tenido variación en forma, tamaño y características del margen del istmo, y la superficie es glabra o cubierta por tricomas de diferentes tipos. La diversidad morfológica de los tricomas se vuelve particularmente relevante para la descripción taxonómica. Los tipos de tricomas presentes en la superficie de los frutos Desmodium, proporcionan datos para la identificación y clasificación de las especies en el Estado de Santa Catarina, Brasil. Tres frutos de cada especie fueron recogidos y depositados en el Herbario (HBR y FLOR, Santa Catarina, Brasil). Algunas muestras fueron rehidratadas y examinadas usando microscopía de luz (LM), las secciones fueron expuestas a los siguientes reactivos histoquímicos: Sudan III para los aceites y Tionina para mucílago. Los aspectos estructurales de los tricomas se pueden clasificar en uni o multicelulares y pueden todavía ser simples, es decir, no glandular o glandular. Por medio del uso de la microscopía electrónica de barrido (SEM), cinco tipos de tricomas se han identificado y analizado entre las especies de Desmodium estudiadas: uncinado, uniseriado, globoso multicelular, globoso unicelular y subulado. Características como el margen del lomento y la forma del artículo, indumento glabrescente o piloso, tipo de tricomas con o sin células epidérmicas papilosas, y estrías epicuticulares mostraron valor de diagnóstico relevante. La clave de identificación fue desarrollada para especies de Desmodium del Estado de Santa Catarina, Brasil, basado en caracteres macro y micromorfológicos del fruto.

Palabras clave: dispersión, clave de identificación, microscopía electrónica de barrido (SEM), estructuras secretoras, taxonomía, tricomas.

\section{REFERENCES}

Agbagwa, I. O. \& Okoli, B. E. (2005). Fruit Epidermal Micromorphology in the Systematics of Abrus Adanson (Papilionaceae) in Parts of Tropical West Africa. Asian Journal of Plant Sciences, 4(6), 652-659.

Akcin, O. E. (2008). Seed coat and fruit surface micromorphology of some Cynoglossum L. (Boraginaceae) species. Bangladesh Journal of Botany, 37(2), 115-119.

Ávalos, S. V. \& Salinas, A. D. (2003). Los tricomas foliares en la caracterización de un grupo de especies del género Quercus, sección Lobatae (Fagaceae). Anales del Instituto de Biología, Universidad Nacional Autónoma de México, Serie Botánica, 74(1), 5-15.

Azevedo, M. G. (1981). O gênero Desmodium Desv. no Brasil: considerações taxonômicas (Master's thesis, Universidade Estadual de Campinas, Brasil). Retrieved from http://www.bibliotecadigital.unicamp.br/ document $/$ ? code $=$ vtls 000075165

Barroso, G. M., Morim, M. P., Peixoto, A. L., \& Ichaso, C. L. F. (1999). Frutos e sementes - morfologia aplicada à sistemática de dicotiledôneas. Viçosa: Editora UFV.

Barthlott, W. (1990). Scanning electron microscopy of the epidermal surface in plants. In D. Claugher (Ed.), Scanning Electron Microscopy in Taxonomy and Functional Morphology (pp. 69-94). Oxford: Clarendon Press.

Barthlott, W., Neinhuis, C., Cutler, D., Ditsch, F., Meusel, I., Theisen, I., \& Wilhelmi, H. (1998). Classification and terminology of plant epicuticular waxes. Botanical Journal of the Linnean Society, 126(3), 237-260.

Bersier, J. D. \& Bocquet, G. (1960). Les méthodes d'éclaircissement en vascularisation et en morphogénie vegetables comparés. Archives des Sciences, $13,555-566$.

Costa, A. F. (1982). Farmacognosia: farmacognosia experimental. Lisboa: Fundação Calouste Gulbenkian.

Cutter, E. G. (1978). Plant anatomy. London: Edward Arnold Publishers. 
Fahn, A. \& Cutler, D. F. (1992). Xerophytes. Germany: Gebrüder Borntraeger.

Holmgren, P. K., Holmgren, N. H., \& Barnett, L. C. (1990). Index Herbariorum Part I: The Herbaria of the World. New York: New York Botanical Garden.

Kaya, A., Ünal, M., Özgökçe, F., Doğan, B., \& Martin, E. (2011). Fruit and seed morphology of six species previously placed in Malcolmia (Brassicaceae) in Turkey and their taxonomic value. Turkish Journal of Botany, 35, 653-662.

Larcher, W. (2000). Ecofisiologia Vegetal. São Carlos: Editora Rima.

Lima, L. C. P., Oliveira, M. L. A. A., \& Tozzi, A. M. G. A. (2014). Desmodium Desv. In Lista de Espécies da Flora do Brasil. Rio de Janeiro: Jardim Botânico do Rio de Janeiro. Retrieved from http://floradobrasil. jbrj.gov.br/jabot/floradobrasil/FB22930)

Lima, L. C. P. (2011). Estudos Filogenéticos em Desmodium Desv. (Leguminosae-Papilionoideae) na América do Sul e Revisão Taxonômica das Espécies Brasileiras (Doctoral Dissertation, Universidade Estadual de Feira de Santana, Brasil). Retrieved from http://www2.uefs.br/ppgbot/pdf_dissertacoes_teses/ doutorado/2011/TeseFinal_LauraLima.pdf

Monteiro, W. R., Castro, M. M., \& Giulietti, A. M. (1985). Aspects of leaf structure of some species of Leiotrix Ruhl. (Eriocaulaceae) from Serra do Cipó (Minas
Gerais, Brasil). Revista Brasileira de Botânica, 7, 137-147.

Ohashi, H. (2014). Tribe Desmodieae. In G. P. Lewis, B. Schrire, B. Mackinder, \& M. Lock (Eds.), Legumes of the World. Kew: Royal Botanic Gardens.

Oliveira, M. L. A. A. (1983). Estudo Taxonômico do gênero Desmodium Desv. (Leguminosae, Faboideae, Desmodieae). Iheringia, Série Botânica, 31, 37-104.

Oliveira, M. L. A. A. (1990). Adições para o gênero Desmodium Desvaux (Leguminosae-Faboideae) no Rio Grande do Sul, Brasil. Iheringia, Série Botânica, 40, 77-87.

Ritter, M. R. \& Miotto, S. T. S. (2006). Micromorfologia da superfície do fruto de espécies de Mikania Willd. (Asteraceae) ocorrentes no Estado do Rio Grande do Sul, Brasil. Acta Botanica Brasílica, 20, 241-247.

Setubal, R. B., Lima, L. C. P., \& Grings, M. (2010). Espécie campestre provavelmente extinta (Desmodium craspediferum Azevedo \& Oliveira, Fabaceae) reencontrada no Rio Grande do Sul, Brasil. Revista Brasileira de Biociência, 8, 432-438.

Werker, E. (2000). Trichome Diversity and Development. In D. L. Hallahan \& J. C. Gray (Eds.), Advances in Botanical Research Incorporating Advances in Plant Pathology: Plant Trichomes (Vol. 31, pp. 1-35). London: Academic Press. 